\section{The difference of corrosion resistance between NiTi archwires and NiTi with additional cooper archwires in artificial saliva}

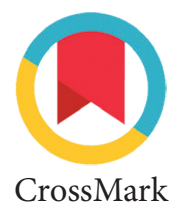

\author{
Eddy H. Habar, ${ }^{*}$ Fransiske Tatengkeng*
}

\title{
Abstract
}

Objective: The aim of this experiment showed the difference of corrosion resistance between Nickel-Titanium (NiTi) archwire and NiTi archwire with additional cooper (NiTi-Cu) in artificial saliva.

Material and Methods: This research was conducted in these laboratory experiments, immersed the NiTi archwires and NiTi-Cu archwires on artificial saliva at $\mathrm{pH}=7$ and incubated on $37^{\circ} \mathrm{C}$, with the ratio of the archwire and the saliva was $0.02 \mathrm{gr}: 1 \mathrm{ml}$ during 1 day, 33 days and 66 days.
Results: Corrosion resistances reviewed by average saliva artificial contained ion Ni after immersed 1 day of NiTi archwires and NiTi-Cu were $0.033 \pm 0.000$, and after immersed 33 days were $0.053 \pm 0.022$ and $0.101 \pm 0.050$, and after 66 days immersed were $0.101 \pm 0.050$ and $8.052 \pm 3.4667$.

Conclusion: Based on research conducted, NiTi archwire more resistant to corrosion than NiTi-Cu, ion Ni released shown higher concentration in NiTi-Cu than NiTi.
Department of Orthodontics, Faculty of Dentistry, Hasanuddin University, Makassar, Indonesia
*Correspondence to: Eddy H. Habar, Fransiske Tatengkeng, Department of Orthodontics, Faculty of Dentistry, Hasanuddin University, Makassar, Indonesia

eddyorto@gmail.com; fransiske.tatengkeng@aiesec.net

Received: 19 April 2020

Revised: 20 June 2020

Accepted: 15 July 2020

Available Online: 1 August 2020

Keywords: Archwire, Corrosion resistance, Nickel Titanium, Nickel Titanium with additional cooper

Cite this Article: Habar EH, Tatengkeng F. 2020. The difference of corrosion resistance between NiTi archwires and NiTi with additional cooper archwires in artificial saliva. Journal of Dentomaxillofacial Science 5(2): 120-123. D0I: 10.15562/jdmfs.v5i2.1089

\section{Introduction}

An orthodontic treatment aim is to improve function by correction of the irregularities, prevent malocclusion and improve personal appearance, which will contribute to the mental as well as to the physical well-being of the individual. ${ }^{1}$ Nowadays the orthodontics science improvement has been a concern in material sciences. Orthodontic materials must have specific characteristics such as biological safety and efficiency, adequate tissue response, and resistance of corrosion. Metal alloys have been extensively used in orthodontic because their elasticity, shape memory, hardness, and stress resistance metal components such as nickel and chromium have been identified as cytotoxic, mutagenic, and allergenic. ${ }^{2}$

The general composition of $\mathrm{NiTi}$ archwires is approximately $53.5 \%$ nickel, $44.9 \%$ titanium, and $1.6 \%$ cobalt. $^{1}$ Nickel Titanium (NiTi) alloys have widespread use in clinical orthodontics because of their excellent properties such as elasticity, tensile strength, and shape memory. ${ }^{1}$

Nickel Titanium with Addition Copper (NiTi-Cu) is a new quaternary alloy with distinct advantages over formerly available NiTi alloys. $\mathrm{NiTi}-\mathrm{Cu}$ are composed, basically, of $42.99 \%$ Titanium, 49.87\% Nickel, 0.50\% Chromium, and 5.64\% Copper. ${ }^{1}$ NiTi-Cu are composed, basically of nickel, titanium, copper, and chromium. The addition of copper decreases the difference between loading and unloading forces causing the delivery of more constant forces for small activations. For presenting the addition of copper (efficient heat conductor) to $\mathrm{NiTi}$, they would present better controlling the transformation temperature of archwires and also increases surface smoothness making the surface roughness similar to untreated TMA wires. ${ }^{1}$

An oral environment is an ideal place for the biodegradation of these alloys. These appliances remain in the mouth average in two years; in spite of their high resistance to corrosion, they release metallic ions into the tissues and saliva. Some of the oral manifestation of cytotoxicity and ion release of orthodontics material such as glossitis, metal taste, gingivitis, peeling lips, erythema multiform, and gingival hypertrophy. ${ }^{3}$ Sub toxic levels of nickel are could cause DNA strand breaks, DNA base damage, inhibition of DNA lesions repair and lead to oral cancer. Small quantities of nickel ion are capable of activating monocytes and possibly enhance an inflammatory response in soft tissues. ${ }^{4}$ Costa et al studied the ions concentration of nickel in patient saliva were $(4.46 \pm 0.68 \mu \mathrm{g} / \mathrm{ml})$ after 44 days using stainless steel brackets and $(0.07 \pm 0.01 \mu \mathrm{g} / \mathrm{ml})$ after 63 days using low-nickel-SS bracket. ${ }^{5}$

The National Academy of Sciences (NAS) study concluded that workers directly exposed to nickel increase the incidence of lung cancer, cancer of the nasal cavity, epidermoid, and anaplastic pleomorphic cancer. Another effect is respiratory disorders, 
asthma, abdominal pain, levels of excess protein in the urine), skin allergies, cancer, and pregnancy disorders. ${ }^{1,6-8}$

To address these important issues, the present study was conducted in vitro to investigate and to determine the differences of corrosion resistance based on Nickel ions released activity between Nickel-Titanium (NiTi) and Nickel-Titanium with Addition Cooper (NiTi-Cu) archwires after immersion in artificial saliva.

\section{Material and Methods}

This experimental study using pre-test and posttest method with control group design. The sample calculation using Federer formula with the following details: $(\mathrm{y}-1) \times(\mathrm{r}-1) \geq 15$. NiTi and NiTi-Cu archwires (TC Yancheng Medical Equipment Co.Ltd) $0.14 \mathrm{~mm}$ ovoid form. Two litres of "Fusayama Meyer" artificial saliva with $\mathrm{pH}$ value was 7.0 consisted of $\mathrm{KCL}(0.4 \mathrm{~g} / \mathrm{L}), \mathrm{NaCl}(0.4 \mathrm{~g} / \mathrm{L})$, $\mathrm{CaCl}_{2} .2 \mathrm{H}_{2} \mathrm{O}(0.906 \mathrm{~g} / \mathrm{L}), \mathrm{NaH}_{2} \mathrm{PO}_{4} .2 \mathrm{H}_{2} \mathrm{O}(0.609$ $\mathrm{g} / \mathrm{L}), \mathrm{NaS}_{2} \cdot 9 \mathrm{H}_{2} \mathrm{O}(0.005 \mathrm{~g} / \mathrm{L})$ and Urea $(1 \mathrm{~g} / \mathrm{L})$ was formulated at Biochemical Laboratory (Faculty of Mathematics and Natural Sciences, Hasanuddin University), incubated on $37^{\circ} \mathrm{C}$ at Microbiology Laboratory (Faculty of Medicine, Hasanuddin University), and assay tested at Forensic Laboratory (Makassar State Police Department)

The artificial saliva was placed into 24 tubes, then divided into three groups. Each tube contains
$25 \mathrm{ml}$ of artificial saliva. The first group, be given a label from A1 to A8 in each tube, will be immersed with NiTi archwires. The second group, be given a label from B1 to B8 in each tube, will be immersed with $\mathrm{NiTi}-\mathrm{Cu}$ archwires, and another group was the control group, be given a label from $\mathrm{C} 1$ to $\mathrm{C} 8$, will be immersed with no treatment. Each sample contained artificial saliva which immersed with NiTi and $\mathrm{NiTi}-\mathrm{Cu}$ archwires with a ratio of $0.02 \mathrm{gr}$ : $1 \mathrm{ml}$. Archwires were cut 0,5 gr and immersed into $25 \mathrm{ml}$ artificial saliva during 33 and 66 days, respectively. samples were incubated on $37^{\circ} \mathrm{C}$ and will be taken $10 \mathrm{ml}$ to measure the number of Nickel ions released using Atomic Absorption Spectroscopy (AAS).

\section{Results}

Normal data distribution was analyzed using a Shapiro-Wilk test using SPSS version 18 (SPSS Inc., Chicago, IL, USA). All results were collected and analyzed with Repeated ANOVA, then followed up with Post-Hoc test: Tukey's HSD.

Table 1 displays distribution median values of the Nickel ions released at baseline after immersed 33 and 66 days based on archwire materials. The median values of Nickel ions released on the control group, NiTi group, and NiTi-Cu group at baseline showed the same result which was 0.033 . But in the control group, there was no significant difference in the Nickel ions released amount after 33 and 66 days of immersion.

Table 1 Distribution median values of the Nickel ions released at baseline, after immersed 33 days, and 66 days

\begin{tabular}{|c|c|c|c|c|c|}
\hline \multirow[b]{3}{*}{ Archwires } & \multirow[b]{3}{*}{ n (\%) } & \multicolumn{3}{|c|}{ Nickel ions } & \multirow[b]{3}{*}{ P-value } \\
\hline & & Baseline & 33 days & 66 days & \\
\hline & & Mean \pm SD & Mean \pm SD & Mean \pm SD & \\
\hline Control & $8(33 \%)$ & $0.033 \pm$ & $0.033 \pm$ & $0.033 \pm$ & $0.000^{*}$ \\
\hline $\mathrm{NiTi}$ & $8(33 \%)$ & $0.033 \pm 0.000$ & $0.053 \pm 0.021$ & $4.230 \pm 2.888$ & $0.012^{*}$ \\
\hline $\mathrm{NiTi}-\mathrm{Cu}$ & $8(33 \%)$ & $0.033 \pm 0.000$ & $0.101 \pm 0.050$ & $8.052 \pm 3.4667$ & $0.002^{*}$ \\
\hline Total & $24(100 \%)$ & & & & \\
\hline
\end{tabular}

${ }^{*}$ Repeated ANOVA test; $\mathrm{p}<0.05$

Table 2 Comparison result test of Nickel ions released at baseline, after immersed 33 and 66 days

\begin{tabular}{|c|c|c|c|c|c|}
\hline Archwires & Time (i) & Comparison & Mean Difference (i-j) & 95\% Cl (min-max) & P-value \\
\hline \multirow[t]{3}{*}{$\mathrm{NiTi}$} & \multirow{2}{*}{ baseline } & 33 days & -0.020 & $-0.044-0.004$ & 0.104 \\
\hline & & 66 days & -4.197 & $-7.931--1.004$ & $0.014^{\star}$ \\
\hline & 33 days & 66 days & -4.177 & $-7.370--0.984$ & $0.014^{*}$ \\
\hline \multirow[t]{3}{*}{$\mathrm{NiTiCu}$} & \multirow{2}{*}{ baseline } & 33 days & -0.069 & $-0.124--0.013$ & $0.019^{*}$ \\
\hline & & 66 days & -8.020 & $-11.853--4.186$ & $0.001^{\star}$ \\
\hline & 33 days & 66 days & -7.951 & $-11.766--4.136$ & $0.001^{\star}$ \\
\hline
\end{tabular}

${ }^{*}$ Post-Hoc test; Tukey's HSD (High Significant Difference); $\mathrm{p}<0.05$; significant 
Table 3 Comparison of nickel ions released after immersed 33 days and 66 days between NiTi and NiTiCu

\begin{tabular}{|c|c|c|}
\hline & NiTi archwires & NiTiCu archwires \\
\hline Variables & Mean \pm SD & Mean \pm SD \\
\hline 33 days & $0.020 \pm 0.021$ & $0.0687 \pm 0.0503$ \\
\hline Comparison & \multicolumn{2}{|c|}{-0.0486} \\
\hline 95\% CI (min-max) & \multicolumn{2}{|c|}{$-0.090--0.007$} \\
\hline p-value & \multicolumn{2}{|c|}{$0.025^{\star}$} \\
\hline 66 days & $4.177 \pm 2.887$ & $7.951 \pm 3.450^{*}$ \\
\hline Comparison & \multicolumn{2}{|c|}{-3.7739} \\
\hline 95\% CI (min-max) & \multicolumn{2}{|c|}{$-7.1858--0.3619$} \\
\hline $\mathrm{p}$-value & \multicolumn{2}{|c|}{$0.033^{*}$} \\
\hline
\end{tabular}

${ }^{*}$ Independent sample t-test; $\mathrm{p}<0.05$;significant.

After immersion during 33 days and 66 days, Nickel ions released were increased for $\mathrm{NiTi}$ and $\mathrm{NiTiCu}$. Nickel ions released were increased to 0.053 for NiTi and 0.101 for NiTiCu archwires. It had a correlation with the median values of Nickel ion released after immersed 66 days, it was 4.230 for NiTi and 8.052 for NiTiCu.

Table 2 display result of Pos-hoc test showed that at each time interval the amount of Nickel ions released from archwires were significantly different. For NiTi, the comparison value was 0.020 between baseline and after immersed 33 days. The comparison value between baseline and after immersed 66 days was 4.197 and also 4.177 for comparison value between immersed 33 days and 66 days. Therefore, for NiTi-Cu archwires, comparison value between baseline and after immersed 33 days was $0.069,8.020$ for baseline and after immersed 66 days, and 7.951 for immersed 33 days.

Table 3 showed that there is a comparison about 0.020 points for NiTi after immersion and 0.0678 point for NiTi-Cu after immersion. Then, if both of archwires were compared, there are 0.0486 point comparison values. Comparison values for $\mathrm{NiTi}-\mathrm{Cu}$ were higher than $\mathrm{NiTi}$. This was also displayed range value for $95 \%$ CI was 0.090-0.007.

\section{Discussion}

Based on different treatment that has been done for three groups, statistical analysis showed significant differences $(p<0.05)$ between NiTi and NiTi-Cu. We found that in NiTi-Cu archwires was released more Nickel ions than NiTi archwires. The addition of Copper in NiTi-Cu archwires increases potential reduction or $\mathrm{E}_{\mathrm{o}}$ cells. In the corrosion process, an electrochemical process will involve reduction and oxidation. Both of these processes depend on the value of the potential electrode of ions.
The value of the potential electrode standard $\left(\mathrm{E}_{\mathrm{o}}\right)$ at $25^{\circ} \mathrm{C}$ temperature was +0.52 for $\mathrm{Ni}$ ions and -0.23 for $\mathrm{Cu}$ ions. The $\mathrm{E}_{0}$ value of both types of ion was $+0.73 .{ }^{9,10}$ Because Eo $>0$, reduction and oxidation reaction takes place spontaneously, where $\mathrm{Ni}$ ions will be reduced and $\mathrm{Cu}$ will be oxidated. Potential oxidation and reduction could not have occurred without the presence of water or contact with oxygen. In other words, when a chemical bond immersed in a solution and/or contact with oxygen, the electrochemical processes of corrosion will occur. In this study, the electrochemical processes indicate that $\mathrm{Cu}$ ions able to exert $\mathrm{Ni}$ ions to be reduction that causes Nickel ions were released more in NiTi-Cu than NiTi archwires.

This study has a similar result with Senkutvan et al. ${ }^{11}$ that showed the significantly statistically significant amount of $\mathrm{Ni}$ and $\mathrm{Ti}$ ions release from artificial saliva. Wide variation in concentration of Ni released from brackets and bands combined. However, the amount of $\mathrm{Ni}$ ions released in all test solutions diminished with time and was below the critical value necessary to induce allergy and below daily dietary intake level. ${ }^{11}$

Jamilian et al. ${ }^{12}$ reported that Chromium and nickel ion was released more in NiTi wire in all solutions compare with Stainless Steel wire. The lowest increase rate also was seen in artificial saliva after immersed 1, 6, 24 hours and 7 days. ${ }^{12}$

Huang et al. ${ }^{13}$ reported the number of metal ions released was increased with the immersion period in all test solutions, while the average ion released per day was decreased with the immersion period. The amount of metal ions released in $\mathrm{pH} 3.75$ solution was much less than that in $\mathrm{pH} 2.5$ solution. A similar order of magnitude between the amount of $\mathrm{Ni}$ and $\mathrm{Ti}$ ions released was observed for all $\mathrm{NiTi}$ wires tested in $\mathrm{pH} 2.5$ solution; while in $\mathrm{pH} 3.75$ solution, the number of $\mathrm{Ti}$ ions released compared with $\mathrm{Ni}$ ions was of a much smaller quantity. Pre-existed surface defects of NiTi wire might be the preferred sites for corrosion, while NiTi wire with a rougher surface did not exhibit a higher ion release. The average amount of $\mathrm{Ni}$ ions released per day from the tested NiTi wires in artificial saliva with various acidities was well below the critical concentration necessary to induce allergy and under daily dietary intake level. According to the release amount of $\mathrm{Ti}$ ions, the passive film (mainly $\mathrm{TiO} 2$ ) on NiTi wires was very protective against corrosion in the slightly acidic artificial saliva. ${ }^{13}$

That Stainless steel archwires released the greatest amount of nickel and chromium ions at both 28 days periods after immersed in the distilled water. The lowest amount of nickel and chromium in both periods was released from NiTi and HANT 
archwires, respectively nickel ion release decreased over time while the chromium release increased. ${ }^{14-16}$

A various study reported a release of $20 \mu \mathrm{g}$ of nickel per day from a simulated full mouth orthodontic appliance. In this study, the total release of nickel values was well below the normal daily intake of Ni 200-300 $\mu \mathrm{g} /$ day. However, the amounts are not directly comparable because the amount of nickel required to create contact hypersensitivity reactions depends on the individual. The study have reported a case of severe allergic reactions after insertion of $\mathrm{NiTi}$ archwire in a $\mathrm{Ni}$ sensitive patient. $^{15}$

Hence, orthodontic treatment for nickel sensitive patients may prove challenging. Further studies are required to examine the cytotoxic effects of released nickel in vitro cell cultures and the level of the corrosive materials which absorbed by the patients. Recently, Ni free brackets like titanium brackets and ceramic brackets can be used effectively for nickel sensitive patients. ${ }^{9}$ Among the archwires ion-implanted NiTi can be used instead of untreated NiTi wires. Besides that, further studies should be designed to measure the nickel content in oral tissues and its possible adverse cellular interactions. ${ }^{11}$

\section{Conclusion}

Based on the result, we may conclude that NiTi was more resistant to corrosion than NiTi with additional cooper (NiTi-Cu). Nickel ions were released more in NiTi-Cu archwires compared with $\mathrm{NiTi}$ archwires in artificial saliva. The amount of Nickel ion release in both of archwires was increased in all time intervals until 66 days.

\section{Acknowledgment}

Thank you very much to Faculty of Dentistry Hasanuddin University for the support this article.

\section{Conflict of Interest}

The authors report no conflict of interest.

\section{References}

1. Singh G. Textbook of orthodontics. New Delhi: Jaypee Brothers Publishers; 2008.

2. Mikulewicz M, Chojnacka K, Woźniak B, et al. Release of metal ions from orthodontic appliances: an in vitro study. Biol Trace Elem Res 2012;146: 272-280.

3. Fernández-Miñano E, Ortiz $\mathrm{C}$, Vicente $\mathrm{A}$, et al. Metallic ion content and damage to the DNA in oral mucosa cells of children with fixed orthodontic appliances. Biometals 2011;24: 935.

4. Kawanishi S, Oikawa S, Inoue S, et al. Distinct mechanisms of oxidative DNA damage induced by carcinogenic nickel subsulfide and nickel oxides. Environ Health Perspect 2002;110: 789-791.

5. Costa MT, Lenza MA, Gosch CS, et al. In vitro evaluation of corrosion and cytotoxicity of orthodontic brackets. J Dent Res 2007;86: 441-445.

6. Das KK, Das SN, Dhundasi SA. Nickel, its adverse health effects \& oxidative stress. Indian J Med Res 2008;128: 412.

7. Trombetta D, Mondello MR, Cimino F, et al. Toxic effect of nickel in an in vitro model of human oral epithelium. Toxicol Lett 2005;159: 219-225.

8. Barcelos AM, Luna AS, Ferreira N de A, et al. Corrosion evaluation of orthodontic wires in artificial saliva solutions by using response surface methodology. Materials Res 2013;16: 50-64

9. Moresca R. Orthodontic treatment time: can it be shortened?. Dental Press J Orthod 2018;23: 90-105.

10. Melo AC, Carneiro LO, Pontes LF, et al. Factors related to orthodontic treatment time in adult patients. Dental Press J Orthod 2013;18: 59-63.

11. Senkutvan RS, Jacob S, Charles A, et al. Evaluation of nickel ion release from various orthodontic arch wires: An in vitro study. J Int Soc Prev Comm Dentist 2014;4: 12.

12. Jamilian A, Moghaddas O, Toopchi S, et al. Comparison of nickel and chromium ions released from stainless steel and NiTi wires after immersion in Oral $\mathrm{B}^{\circ}$, Orthokin ${ }^{\circ}$ and artificial saliva. J Contemp Dent Prac 2014;15: 403-406.

13. Huang $\mathrm{H}-\mathrm{H}$, Chiu $\mathrm{Y}-\mathrm{H}$, Lee $\mathrm{T}-\mathrm{H}$, et al. Ion release from $\mathrm{NiTi}$ orthodontic wires in artificial saliva with various acidities. Biomaterials 2003;24: 3585-3592.

14. Arab S, Cham MH, Morsaghian M, et al. Evaluation of nickel and chromium ion release from stainless steel, HANT and NiTi arch wires in two 28-day time Spans. Iran J Ortho 2015;10: e4863.

15. Tariq A, Jamshaid M, Majeed I. Xerostomia: post radiation management strategies. Int J Pharmacol Res Allied Sci 2015;4: 35-47.

16. Nahusona DR, Meydina A. Identification of dominant aerob bacteri in saliva of the patient with fixed orthodontic appliance. J Dentomaxillofac Sci 2018;3: 96-99.

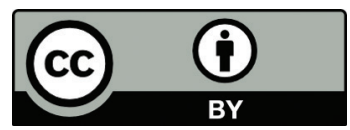

This work is licensed under a Creative Commons Attribution 